\title{
Assessment of the status of the coastal groundfish assemblage exploited by the Viareggio fleet (Southern Ligurian Sea)
}

\author{
ALVARO ABELLA, MICHELA RIA and CECILIA MANCUSI \\ Agenzia Regionale Protezione Ambiente Toscana, Area MARE, Via Marradi 114, Livorno, Italia. \\ E-mail: a.abella@arpat.toscana.it
}

\begin{abstract}
SUMMARY: The coastal demersal fish assemblage exploited commercially by the Viareggio fleet was assessed in order to define its exploitation status and sustainability. A production model was used provided management benchmarks for the species for which available data are limited. The ASPIC Surplus production model was used. The results showed a depleted population for most of the species involved $\left(B_{2008} / B_{0}\right.$ between 0.05 and 0.35$)$ with high relative fishing mortality $\left(F_{2008} / F_{M S Y}\right.$ between 1.18 and 1.64). Population projections using ASPIC-P allowed the exploitation strategies to be evaluated for a $10-$ year period. None of the populations are predicted to recover to $B_{M S Y}$ if fishing effort remains at the 2008 levels. A reduction in effort of about $40 \%$ should increase the biomass in the medium-term of most of the species to $B_{M S Y}$ or over, with a fairly good increase in yields of the most valuable species.
\end{abstract}

Keywords: NW Mediterranean, multispecies fisheries, production models, stock assessment, commercial fisheries, forecasting.

RESUMEN: EVAluación del eStado de los estocs costeros explotados por la flota de Viareggio (Mar Ligur MERIDIONAL). - El conjunto de especies costeras explotado comercialmente por la flota de Viareggio fue evaluado para definir su estado de explotación y sostenibilidad. El uso de un modelo de producción permitió definir pautas de manejo pesquero para estas especies para las que los datos disponibles son limitados. Se utilizó el modelo de producción excedente ASPIC. Los resultados mostraron para la mayoría de las especies, biomasas drásticamente reducidas $\left(B_{2008} / B_{0}\right.$ entre 0.05 y $0.35)$ con altos valores relativos de mortalidad por pesca $\left(F_{2008} / F_{M S Y}\right.$ entre 1.18 y 1.64). Proyecciones realizadas con ASPIC permitieron evaluar estrategias de explotación para un periodo de diez años. Manteniendo el esfuerzo a nivel del 2008, para ninguna especie se prevé que la recuperación de la población alcance el nivel de $B_{M S Y}$. Una reducción del esfuerzo del $40 \%$ debería conducir a un incremento, a medio plazo, de la biomasa de casi todas las especies por encima del $B_{M S Y}$, incrementándose asimismo sustancialmente los rendimientos de las especies más importantes.

Palabras clave: Mediterráneo nord-occidental, pesquerías multiespecíficas, modelos de producción, evaluación de estocs, pesca comercial, proyecciones.

\section{INTRODUCTION}

One of the largest Italian industrial fishing fleets operates in the Viareggio port. It is composed of 128 vessels, with 57 trawlers targeting coastal or deep-sea resources and 68 involved in small-scale fisheries. Viareggio fishing vessels have different sizes and tonnage, but relatively small-sized vessels (more than $60 \%$ of the vessels have GT $<20, \mathrm{~kW}<150$ and a total length
$<15$ metres) are most common. Most of them (mainly those that are smaller) target demersal resources and in general use bottom trawl nets, which are called volantina locally.

Despite the importance of the fishing activities in this port, official statistics do not furnish enough information on operation areas, gear characteristics or the target species and effective effort exerted by a single vessel during each fishing trip. In order to fill the gap, 
an ad hoc catch assessment survey was initiated in 1990 and is still under way.

After the World Summit on Sustainable Development (WSDS) held in Johannesburg in 2002, the EU Member States signed to limit fishing in order to return the major fish stocks under their jurisdiction to sustainable levels by maintaining or restoring stocks in order to produce the maximum sustainable yield (EC, 2006). This implies moving from a framework of precautionary limit reference points towards achieving target reference points (MSY) and thresholds, as well as defining overfishing based on these $M S Y$ reference points. The estimates of $M S Y$ and correlated exploitation rates, often derived from surplus-production models, are also the basis for management in the U.S. fisheries (U.S. Department of Commerce, 1996, 1998).

This study analyses the stocks exploited by the fishing fleet targeting the assemblage of coastal demersal resources. The main goals are to define the current exploitation status of the more important species involved in this fishery and estimate the level of change in fishing effort necessary to increase the biomass of most of the stocks in this multispecies fishery to $B_{M S Y}$ levels. Although the ultimate goal for this stock assessment is to use the data in age-structured models, due to the lack of time series of reliable information on the age/size structure of the catches, it will be a number of years before these modelling approaches can be implemented. As an alternative approach, a non-equilibrium surplus production model was used to analyse a 19-year time series of catch and effort data. Although production models have been used widely for assessing several species (Booth and Punt, 1998; Cadrin and Hatfield, 2002; Vaughan and Prager, 2002), there are only a few recent examples of these approaches being applied in the Mediterranean Sea. In the north-western Mediterranean, Carbonell and Azevedo (2003) used these approaches to assess the exploitation status of red shrimp Aristaeus antennatus.

It has been found (Ludwig and Walters, 1989, Hilborn and Walters, 1992) that non-equilibrium surplus production models can provide estimates that are more precise and accurate than those obtained with more complex approaches.

\section{MATERIALS AND METHODS}

Landings and specific effort data of the Viareggio fleet for the period from 1990 to 2008 were analysed. Details on sampling design can be found in Abella et al. (2001). The statistical population analysed is constituted by all the vessels that operate during the year from the Viareggio port using bottom trawl nets and targeting coastal demersal species.

The basic survey design was a simple random sample. On average, during each visit, more than $50 \%$ of the vessels were sampled by direct observation of the landings. Field work was performed by well trained staff and information gathered on a monthly basis.
Fishers were interviewed personally during the landing procedures and asked questions concerning the gear used, fishing area, depth and the number and duration of tows. Observing landings directly allows the number of boxes to be quantified by species, and this was successively transformed into weight. The abundance index LPUE (landings per unit effort) was calculated for each species as "total weight in $\mathrm{kg}$ of the landings/ fishing effort" with effort expressed as effective hours of fishing excluding the time spent setting and hauling or going to the fishing grounds. The discard rate values for the analysed species can be considered negligible in this coastal fishery and these rates remained unchanged throughout the studied period.

It was considered unnecessary to standardise fishing power for the vessels after an analysis of the catch performance of the vessels exploiting the coastal demersal assemblage was carried out by size (length, engine power, gross tonnage). The analysis correlated the main structural characteristics of the vessels with their corresponding catch rates obtained in the same time and place, and showed that, within the narrow size range of the vessels in the fishery, there were very few differences in their catch performance. Moreover, the general distribution of the fleet structure remained almost unchanged over the considered time period. The mean duration of hauls for each trip for each month derived from the sampling at the landing site was used with the available information on number of fishing days per vessel for each month to find the total fishing time. The detail levels of this information allowed effort to be expressed as hours actually devoted to fishing. Mean LPUEs $(\mathrm{kg} / \mathrm{h})$ were used for estimating total catch per month by combining this information with the information on fleet activity expressed in fishing hours.

The study regards the group of vessels, namely the coastal trawl fishery, operating near the coast (in general up to $150 \mathrm{~m}$ from the shore) that targets a multispecific groundfish assemblage. The analyses were performed on each of the 8 main species that on average accounted for $65 \%$ of the mean total landings (Squilla mantis, Sepia officinalis, Mullus barbatus, Merluccius merluccius, Penaeus kerathurus, Eledone cirrhosa, Gobius niger and Chelidonichthys lucerna) and also on the entire species assemblage. With the exception of European hake (Merluccius merluccius), that is also exploited by trawlers operating in deeper waters and by the artisanal fleet, the other species can be considered to be exploited almost exclusively by the coastal bottom trawlers. The spatial distribution of fishing effort is shown in Figure 1.

In order to assess the current situation of these stocks and of the entire assemblage, an approach based on a biomass dynamic model was chosen in order to define the Maximum Sustainable Yield. The analyses were performed using the ASPIC 5.33 software (A StockProduction model Incorporating Covariates) (Prager, 1994, 2005). This program implements a non-equilib- 


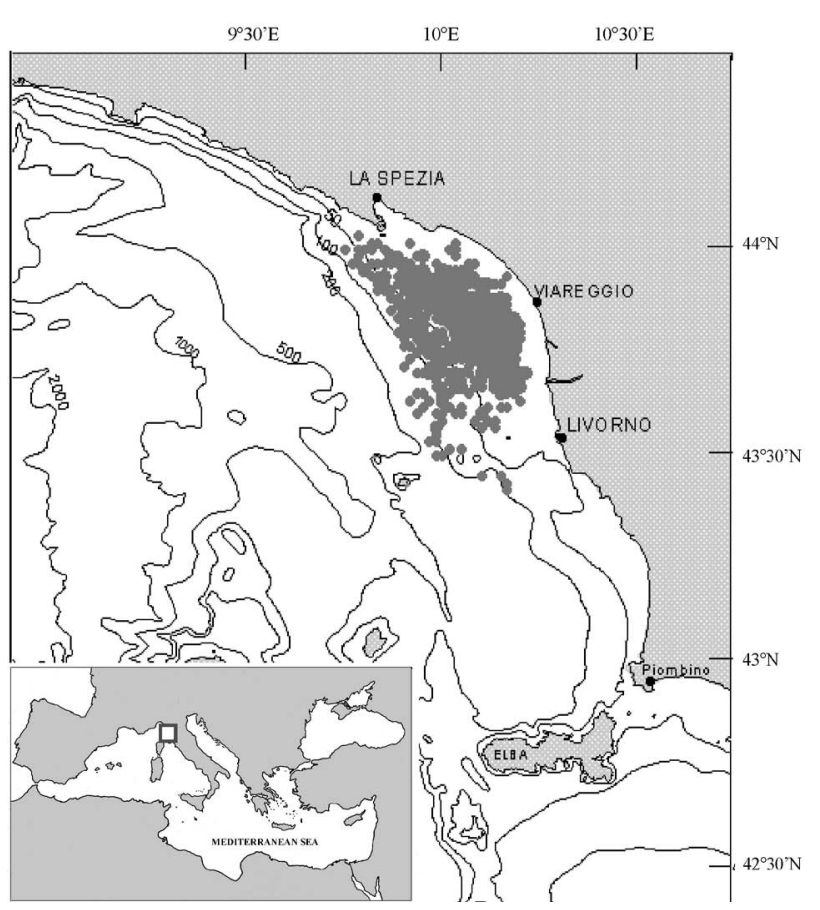

FIG. 1. - Spatial distribution in 2006 of fishing effort of the fraction of the fleet targeting coastal groundfish with bottom trawl nets.

rium, continuous-time, observation-error estimator for the production model (Schnute, 1977; Prager, 1994). The main difference equation of the model in discrete form is the following:

$$
B_{t+1}=B_{t}+(r-q f) B_{t}-\left(\frac{r}{K}\right) B_{t}^{2}
$$

where $B_{\mathrm{t}}$ is the population biomass at time $\mathrm{t}, K$ is the carrying capacity, $r$ is the intrinsic rate of increase, $q$ is the catchability coefficient and $f$ is fishing effort.

Data was fitted with a regular least squares procedure that can be used in conjunction with a robust objective function (least absolute values), which uses an iterative procedure for minimisation, in particular a Simplex-based method.

The parameters are estimated assuming that the errors in yield or effort are multiplicative and have a constant standard deviation. Therefore, the residuals are accumulated in logarithmic transform. The minimised objective function is:

$$
\Omega=\sum_{i=1}^{I} \sum_{j=1}^{N} \omega_{i}\left(\ln \frac{Y_{i j}}{\hat{Y}_{i j}}\right)^{2}
$$

where $I$ indexes the data series, $j$ the year, $\omega$ is the statistical weight of the series, $Y_{i j}$ is the observed yield or biomass index or estimates from series $i$ in year $j$, and $\hat{Y}_{i j}$ is the corresponding predicted value.

ASPIC uses bootstrapping to estimate bias-corrected (BC) confidence intervals for many quantities of interest. Bias-corrected confidence intervals were computed by standard methods (Efron and Gong, 1983).
Production models estimate some quantities more precisely than others. Among those that are estimated more precisely are the maximum sustainable yield $(M S Y)$, optimum effort $\left(f_{\mathrm{MSY}}\right)$ and relative levels of stock biomass and fishing mortality rate.

A number of general assumptions are associated with production models (Quinn and Deriso, 1999): the production over time is assumed to change with population size; the intrinsic rate of population growth $r$ and the carrying capacity $K$ are assumed constant; and any change in the biotic and abiotic environments is ignored.

The production model estimates several benchmarks and status indicators that are useful for understanding biology and improving management. These quantities include relative biomass $\left(B_{\text {curr }} / B_{M S Y}\right)$, relative fishing mortality $\left(F_{c u r r} / F_{M S Y}\right)$, population biomass $(B)$, and maximum sustainable yield (MSY). Point estimates and $80 \%$ confidence intervals for each of these quantities were calculated for each model run.

Considering that the software used produces direct estimations of $B_{1}$ (estimated initial Biomass), $r, K$ and $q$, no educated guesses of any of the parameters were used. However, specific assumptions about population values are required by the model as initial guesses. Starting guess values of $M S Y$ and $K$ were based on the historical information on the size of the commercial catches of the Viareggio fleet and the previous information regarding the level of fishing pressure exerted. Several trials were carried out and fittings analysed in order to quantify the model's sensitivity to the starting values.

The production model was conditioned on catch, given that landings data are assumed to be more precisely measured than effort.

Fishery-dependent data were available from 1990 to 2008 from the bottom trawl fisheries. Abundance indices based on landings-per-unit-effort ( $L P U E)$ for these fisheries were calculated from the annual number of fishing hours and landings in weight $(\mathrm{kg})$.

The population estimates calculated with the surplus production model were used to project the population forward in time for a period of 10 years at different levels of $F$ to evaluate changes in biomass and potential harvest levels. Longer periods for forecasting were considered unsuitable considering that confidence in projection results decreases at longer time intervals. The trends in relative biomass over time for a range of fishing mortality levels were evaluated with $F$ at 2008 levels $\left(F_{\text {curr }}\right)$ then proportional reductions in the mortality rate. The chosen reduction levels of the current $F$ were $0 \%$ (current level of harvest unchanged), 20\%, 40\%, 60\%, $80 \%$ and $100 \%$ (complete cessation of fishing activities). The biomass level reached at the end of the prediction time period under each harvesting scenario was assessed, as well as the number of years required for the population (including $80 \%$ confidence intervals) to rebuild to $B_{M S Y}$. 
TABLE 1. - Specific composition of landings in weight of the volantina coastal fishery in 2006 .

\begin{tabular}{lcc}
\hline Species & Code & $\%$ \\
\hline Squilla mantis & SMS & 21.8 \\
Sepia officinalis & SOF & 11.8 \\
Mullus barbatus & MBA & 9.5 \\
Merluccius merluccius & MME & 4.7 \\
Penaeus kerathurus & PKE & 4.6 \\
Eledone cirrhosa & ECI & 4.5 \\
Gobius niger & GNI & 4.2 \\
Chelidonichthys lucerna & TLU & 4.0 \\
Trachurus mediterraneus & TME & 3.1 \\
Eledone moschata & EMO & 3.0 \\
Raja asterias & RAS & 2.9 \\
Solea vulgaris & SVU & 2.8 \\
Conger conger & CCO & 2.3 \\
Octopus vulgaris & OVU & 1.9 \\
Arnoglossus laterna & ALA & 1.6 \\
Trachinus draco & TDR & 1.1 \\
Alloteuthis media & AME & 1.1 \\
Other species & OTHER & 15.00 \\
\hline
\end{tabular}

\section{RESULTS}

The vessels that use a variant of the traditional Italian bottom otter trawl net called volantina and that fish on coastal grounds make up the largest fraction of the Viareggio trawler fleet, as they perform more than $80 \%$ of the total trips. Figure 1 shows the spatial distribution of effort exerted by these coastal trawlers. This fishery is operative all year round with small seasonal fluctuations in activity. It targets a mixture of species with no constant dominance of any one species (Table 1). The total landings of the coastal trawling is about 1000 tons/year.

The fishery operates in the depth range from 15 to $150 \mathrm{~m}$, but mainly between 20 and $50 \mathrm{~m}$. A trip lasts on average 15 hours, with about 11 hours of effective fishing effort. Three to five tows are made, mainly performed during the daylight hours. Vessels are relatively small, from 11 to $24 \mathrm{~m}$, with an engine power that is generally lower than $200 \mathrm{kw}$.

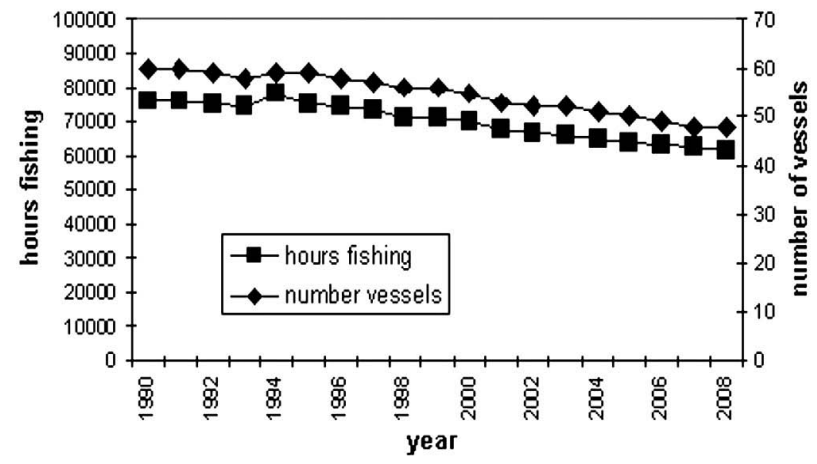

FIG. 2. - Trends of fishing effort (in number of vessels and hours fishing) over the analysed period for the bottom trawl fleet.

The number of vessels that target the coastal groundfish assemblage decreased over the analysed period from about 56 to 44 units (Fig. 2).

Considering that during the study period fishing procedures, technology and daily fishing time per unit vessel did not undergo important changes, an effective reduction in the fishing effort can be assumed. The results for each species and for the species assemblage are shown in Table 2. The current biomass levels are relatively low regarding $K$ estimates, with a $B / K$ rate ranging from $6 \%$ to $35 \%$. Higher $K$ values were estimated for Squilla mantis, Merluccius merluccius and Mullus barbatus. Values of the approximate confidence intervals derived from the bootstrapping procedure were reasonable considering the nature of the analysed data.

Values of $r$ were generally relatively high, which is consistent with the relatively fast turnover that characterises most of the analysed species.

Figure 3 shows the increasing abundance trend for 6 of the 8 selected species. The two exceptions are $M$. merluccius, which showed a negative trend up to year 2000 followed by a fairly stationary status, and Gobius niger which also showed a decreasing trend with more stable $L P U E$ values in the last years. The LPUEs for

TABLE 2. - The main results for the 8 selected species and for the assemblage for the parameters of the population growth model $K$ and $r ; q$, coefficient of catchability; $M S Y, F$ current $\left(F_{\text {curr }}\right), f$ current $\left(f_{\text {curr }}\right)$ and relative values of fishing mortality and fishing effort $\left(F / F_{M S Y}\right.$ and $\left.f / f_{M S Y}\right)$. Bootstrap $80 \%$ confidence intervals are included. Yield and biomass values are expressed in $\mathrm{kg}$ and $F$ in annual rates.

\begin{tabular}{|c|c|c|c|c|c|c|c|}
\hline & Value & Lower bound & Upper bound & & Value & Lower bound & Upper bound \\
\hline \multicolumn{8}{|l|}{ M. barbatus } \\
\hline $\mathrm{K}$ & 1118000 & 857933 & 1771526 & $\mathrm{~B} / \mathrm{B}_{\mathrm{MSY}}$ & 0.471 & 0.251 & 0.596 \\
\hline $\mathrm{q}$ & 0.00001012 & 0.00000815 & 0.00001169 & $\mathrm{~F}_{\text {curr }} / \mathrm{FMSY}$ & 1.27 & 1.019 & 1.731 \\
\hline $\mathrm{Y}_{\mathrm{e}}$ & 192375 & 165100 & 237400 & $\mathrm{Y}_{\mathrm{e}} / \mathrm{MSY}$ & 0.75 & 0.506 & 0.921 \\
\hline MSY & 256500 & 200246 & 352161 & $\mathrm{r}$ & 0.918 & & \\
\hline $\mathrm{B}_{\mathrm{MSY}}$ & 559100 & 450871 & 935935 & $\mathrm{~F}_{\text {curr }}$ & 0.583 & & \\
\hline $\mathrm{F}_{\mathrm{MSY}}^{\mathrm{MSY}}$ & 0.459 & 0.327 & 0.508 & $\mathrm{f}_{\text {curr }}^{\text {curr }}$ & 61726 & & \\
\hline $\mathrm{f}_{\mathrm{MSY}}^{\mathrm{MSY}}$ & 45350 & 41271 & 50044 & $\mathrm{f}_{\text {curr }}^{\text {curr }} / \mathrm{f}_{\mathrm{MSY}}$ & 1.36 & & \\
\hline \multicolumn{8}{|l|}{ E. cirrhosa } \\
\hline $\mathrm{K}$ & 307800 & 287200 & 363800 & $\mathrm{~B} / \mathrm{B}_{\mathrm{MSY}}$ & 0.697 & 0.508 & 0.884 \\
\hline $\mathrm{q}$ & 0.00001212 & 0.0001109 & 0.0001316 & $\mathrm{~F}_{\text {curr }} / \mathrm{FMSY}$ & 0.995 & 0.817 & 1.32 \\
\hline $\mathrm{Y}_{\mathrm{e}}$ & 89600 & 80300 & 97200 & $\mathrm{Y} / \mathrm{e} / \mathrm{MSY}$ & 0.908 & 0.758 & 0.986 \\
\hline MSY & 98700 & 95200 & 102000 & $r$ & 1.282 & & \\
\hline $\mathrm{B}_{\mathrm{MSY}}$ & 154000 & 144000 & 182000 & $\mathrm{~F}_{\text {curr }}$ & 0.638 & & \\
\hline $\mathrm{F}_{\mathrm{MSY}}^{\mathrm{MSY}}$ & 0.641 & 0.563 & 0.682 & $\mathrm{f}_{\text {curr }}^{\text {curr }}$ & 61726 & & \\
\hline $\mathrm{f}_{\mathrm{MSY}}^{\mathrm{MSY}}$ & 51100 & 47600 & 54500 & $\mathrm{f}_{\text {curr }}^{\text {curt }} / \mathrm{f}_{\mathrm{MSY}}$ & 1.21 & & \\
\hline
\end{tabular}


TABLE 2 (cont.). - The main results for the 8 selected species and for the assemblage for the parameters of the population growth model $K$ and $r ; q$, coefficient of catchability; $M S Y, F$ current $\left(F_{c u r r}\right), f$ current $\left(f_{\text {curr }}\right)$ and relative values of fishing mortality and fishing effort $\left(F / F_{M S Y}\right.$ and $f l$ $\left.f_{M S Y}\right)$. Bootstrap $80 \%$ confidence intervals are included. Yield and biomass values are expressed in $\mathrm{kg}$ and $F$ in annual rates.

\begin{tabular}{|c|c|c|c|c|c|c|c|}
\hline & Value & Lower bound & Upper bound & & Value & Lower bound & Upper bound \\
\hline $\begin{array}{l}\text { C. lucerna } \\
\mathrm{K} \\
\mathrm{q} \\
\mathrm{Y}_{\mathrm{e}} \\
\mathrm{MSY} \\
\mathrm{B}_{\mathrm{MSY}} \\
\mathrm{F}_{\mathrm{MSY}} \\
\mathrm{f}_{\mathrm{MSY}}\end{array}$ & $\begin{array}{c}334300 \\
0.0000101 \\
43500 \\
71640 \\
167200 \\
0.429 \\
42840\end{array}$ & $\begin{array}{c}314100 \\
0.00000857 \\
27880 \\
56940 \\
157100 \\
0.318 \\
38110\end{array}$ & $\begin{array}{c}861300 \\
0.00001161 \\
56780 \\
81890 \\
430700 \\
0.467 \\
46960\end{array}$ & $\begin{array}{l}\mathrm{B} / \mathrm{B}_{\mathrm{MSY}} \\
\mathrm{F}_{\text {curr }} / \mathrm{FMSY} \\
\mathrm{Y}_{\mathrm{e}} / \mathrm{MSY} \\
\mathrm{r} \\
\mathrm{F}_{\text {curr }} \\
\mathrm{f}_{\text {curr }} \\
\mathrm{f}_{\text {curr }} / \mathrm{f}_{\mathrm{MSY}}\end{array}$ & $\begin{array}{c}0.373 \\
1.795 \\
0.607 \\
0.857 \\
0.770 \\
61726 \\
1.44\end{array}$ & $\begin{array}{l}0.151 \\
1.387 \\
0.278\end{array}$ & $\begin{array}{c}0.543 \\
2.994 \\
0.79\end{array}$ \\
\hline $\begin{array}{l}\text { S. mantis } \\
\mathrm{K} \\
\mathrm{q} \\
\mathrm{Y}_{\mathrm{e}} \\
\mathrm{MSY} \\
\mathrm{B}_{\mathrm{MSY}} \\
\mathrm{F}_{\mathrm{MSY}} \\
\mathrm{f}_{\mathrm{MSY}}\end{array}$ & $\begin{array}{c}1327000 \\
9.218 \mathrm{E}-06 \\
256600 \\
295000 \\
663700 \\
0.444 \\
48200\end{array}$ & $\begin{array}{c}1015000 \\
0.00000522 \\
236300 \\
247500 \\
507700 \\
0.259 \\
45520\end{array}$ & $\begin{array}{c}2078000 \\
0.00001022 \\
291500 \\
341400 \\
1039000 \\
0.493 \\
53040\end{array}$ & $\begin{array}{l}\mathrm{B} / \mathrm{B}_{\mathrm{MSY}} \\
\mathrm{F}_{\text {curr }} / \mathrm{FMSY} \\
\mathrm{Y}_{\mathrm{e}} / \mathrm{MSY} \\
\mathrm{r} \\
\mathrm{F}_{\text {curr }} \\
\mathrm{f}_{\text {curr }} \\
\mathrm{f}_{\text {curr }} / \mathrm{f}_{\mathrm{MSY}}\end{array}$ & $\begin{array}{c}0.639 \\
1.334 \\
0.87 \\
0.889 \\
0.592 \\
61726 \\
1.28\end{array}$ & $\begin{array}{l}0.538 \\
1.201 \\
0.787\end{array}$ & $\begin{array}{l}0.792 \\
1.479 \\
0.957\end{array}$ \\
\hline $\begin{array}{l}\text { M. merluccius } \\
\mathrm{K} \\
\mathrm{q} \\
\mathrm{Y}_{\mathrm{e}} \\
\mathrm{MSY} \\
\mathrm{B}_{\mathrm{MSY}} \\
\mathrm{F}_{\mathrm{MSY}} \\
\mathrm{f}_{\mathrm{MSY}}\end{array}$ & $\begin{array}{c}1316000 \\
7.587 \mathrm{E}-06 \\
68670 \\
189000 \\
658200 \\
0.287 \\
37850\end{array}$ & $\begin{array}{c}1142000 \\
0.000004004 \\
53270 \\
65640 \\
571200 \\
0.17 \\
33670\end{array}$ & $\begin{array}{c}5911000 \\
0.00000943 \\
87310 \\
211800 \\
2956000 \\
0.358 \\
43210\end{array}$ & $\begin{array}{l}\mathrm{B} / \mathrm{B}_{\mathrm{MSY}} \\
\mathrm{F}_{\text {curr }} / \mathrm{FMSY} \\
\mathrm{Y}_{\mathrm{e}} / \mathrm{MSY} \\
\mathrm{r} \\
\mathrm{F}_{\text {curr }} \\
\mathrm{f}_{\text {curr }} \\
\mathrm{f}_{\text {curr }} / \mathrm{f}_{\mathrm{MSY}}\end{array}$ & $\begin{array}{c}0.202 \\
1.384 \\
0.363 \\
0.574 \\
0.397 \\
61726 \\
1.63\end{array}$ & $\begin{array}{c}0.089 \\
1.101 \\
0.17\end{array}$ & $\begin{array}{c}0.489 \\
1.94 \\
0.739\end{array}$ \\
\hline $\begin{array}{l}\text { G. niger } \\
\mathrm{K} \\
\mathrm{q} \\
\mathrm{Y}_{\mathrm{e}} \\
\mathrm{MSY} \\
\mathrm{B}_{\mathrm{MSY}} \\
\mathrm{F}_{\mathrm{MSY}} \\
\mathrm{f}_{\mathrm{MSY}}\end{array}$ & $\begin{array}{c}664200 \\
0.00001073 \\
26950 \\
110800 \\
332100 \\
0.334 \\
33350\end{array}$ & $\begin{array}{c}632928 \\
0.0000095289 \\
19330 \\
104402 \\
316414 \\
0.290 \\
31169\end{array}$ & $\begin{array}{c}744627 \\
0.0000115958 \\
33910 \\
116422 \\
372364 \\
0.352 \\
35605\end{array}$ & $\begin{array}{l}\mathrm{B} / \mathrm{B}_{\mathrm{MSY}} \\
\mathrm{F}_{\text {curr }} / \mathrm{FMSY} \\
\mathrm{Y}_{\mathrm{e}} / \mathrm{MSY} \\
\mathrm{r} \\
\mathrm{F}_{\text {curr }} \\
\mathrm{f}_{\text {curr }} \\
\mathrm{f}_{\text {curr }} / \mathrm{f}_{\mathrm{MSY}}\end{array}$ & $\begin{array}{c}0.126 \\
1.75 \\
0.243 \\
0.667 \\
0.585 \\
61726 \\
1.85\end{array}$ & $\begin{array}{l}0.088 \\
1.424 \\
0.169\end{array}$ & $\begin{array}{l}0.167 \\
2.275 \\
0.305\end{array}$ \\
\hline $\begin{array}{l}\text { P. kerathurus } \\
\mathrm{K} \\
\mathrm{q} \\
\mathrm{Y}_{\mathrm{e}} \\
\mathrm{MSY} \\
\mathrm{B}_{\mathrm{MSY}} \\
\mathrm{F}_{\mathrm{MSY}} \\
\mathrm{f}_{\mathrm{MSY}}\end{array}$ & $\begin{array}{c}287500 \\
0.00001108 \\
45720 \\
69690 \\
143800 \\
0.478 \\
43120\end{array}$ & $\begin{array}{c}251325 \\
0.00000820 \\
37430 \\
58998 \\
125750 \\
0.391 \\
40766\end{array}$ & $\begin{array}{c}370774 \\
0.00001286 \\
52930 \\
62026 \\
185516 \\
0.540 \\
47913\end{array}$ & $\begin{array}{l}\mathrm{B} / \mathrm{B}_{\mathrm{MSY}} \\
\mathrm{F}_{\text {curr }} / \mathrm{FMSY} \\
\mathrm{Y}_{\mathrm{e}} / \mathrm{MSY} \\
\mathrm{r} \\
\mathrm{F}_{\text {curr }} \\
\mathrm{f}_{\text {curr }} \\
\mathrm{f}_{\text {curr }} / \mathrm{f}_{\mathrm{MSY}}\end{array}$ & $\begin{array}{c}0.422 \\
1.602 \\
0.656 \\
0.954 \\
0.766 \\
61726 \\
1.43\end{array}$ & $\begin{array}{l}0.251 \\
1.418 \\
0.439\end{array}$ & $\begin{array}{l}0.624 \\
2.021 \\
1.417\end{array}$ \\
\hline $\begin{array}{l}\text { S. officinalis } \\
\mathrm{K} \\
\mathrm{q} \\
\mathrm{Y}_{\mathrm{e}} \\
\mathrm{MSY} \\
\mathrm{B}_{\mathrm{MSY}} \\
\mathrm{F}_{\mathrm{MSY}} \\
\mathrm{f}_{\mathrm{MSY}}\end{array}$ & $\begin{array}{c}542300 \\
0.0000139 \\
91930 \\
133200 \\
271100 \\
0.491 \\
43140\end{array}$ & $\begin{array}{c}455130 \\
0.00001253 \\
79950 \\
119149 \\
227523 \\
0.439 \\
41236\end{array}$ & $\begin{array}{c}666326 \\
0.00001649 \\
103700 \\
148051 \\
333152 \\
0.641 \\
46297\end{array}$ & $\begin{array}{l}\mathrm{B} / \mathrm{B}_{\mathrm{MSY}} \\
\mathrm{F}_{\text {curr }} / \mathrm{FMSY} \\
\mathrm{Y}_{\mathrm{e}} / \mathrm{MSY} \\
\mathrm{r} \\
\mathrm{F}_{\text {curr }} \\
\mathrm{f}_{\text {curr }} \\
\mathrm{f}_{\text {curr }} / \mathrm{f}_{\mathrm{MSY}}\end{array}$ & $\begin{array}{c}0.54 \\
1.51 \\
0.69 \\
0.982 \\
0.741 \\
61726 \\
1.43\end{array}$ & $\begin{array}{l}0.453 \\
1.308 \\
0.635\end{array}$ & $\begin{array}{l}0.731 \\
1.737 \\
0.926\end{array}$ \\
\hline $\begin{array}{l}\text { Assemblage } \\
0.929 \\
\mathrm{q} \\
\mathrm{Y}_{\mathrm{e}} \\
\mathrm{MSY} \\
\mathrm{B}_{\mathrm{MSY}} \\
\mathrm{F}_{\mathrm{MSY}} \\
\mathrm{f}_{\mathrm{MSY}}\end{array}$ & $\begin{array}{c}\mathrm{K} \\
6.448 \mathrm{E}-06 \\
1173000 \\
1330000 \\
4174000 \\
0.319 \\
49420\end{array}$ & $\begin{array}{c}8348000 \\
\\
0.000001072 \\
1028000 \\
1047000 \\
2604000 \\
0.077 \\
43490\end{array}$ & $\begin{array}{c}5207000 \\
\\
0.000009127 \\
1412000 \\
2014000 \\
50990000 \\
0.442 \\
63000\end{array}$ & $\begin{array}{l}102000000 \\
\mathrm{~F}_{\text {curr }} / \mathrm{FMSY} \\
\mathrm{Y}_{\mathrm{e}} / \mathrm{MSY} \\
\mathrm{r} \\
\mathrm{F}_{\text {curr }} \\
\mathrm{f}_{\text {curr }} / \mathrm{f}_{\mathrm{f}} \\
\mathrm{f}_{\text {curr }} / \mathrm{f}_{\mathrm{MSY}}\end{array}$ & $\begin{array}{c}\mathrm{B} / \mathrm{B}_{\mathrm{MSY}} \\
1.248 \\
0.816 \\
0.637 \\
0.398 \\
61726 \\
1.25\end{array}$ & $\begin{array}{l}0.656 \\
1.069 \\
0.474\end{array}$ & $\begin{array}{l}0.273 \\
1.543 \\
0.993\end{array}$ \\
\hline
\end{tabular}

the whole assemblage show a constant positive trend. The figure shows the fairly good correspondence between the observed and predicted $L P U E$ values obtained with the model parameters defined. Values of the determination coefficient $r^{2}$ were relatively high for almost all the species. Unweighted log residuals between observed and estimated values do not show any clear trend.

According to the results derived from the surplus production model runs, the current levels of $f$ and $F$ for 

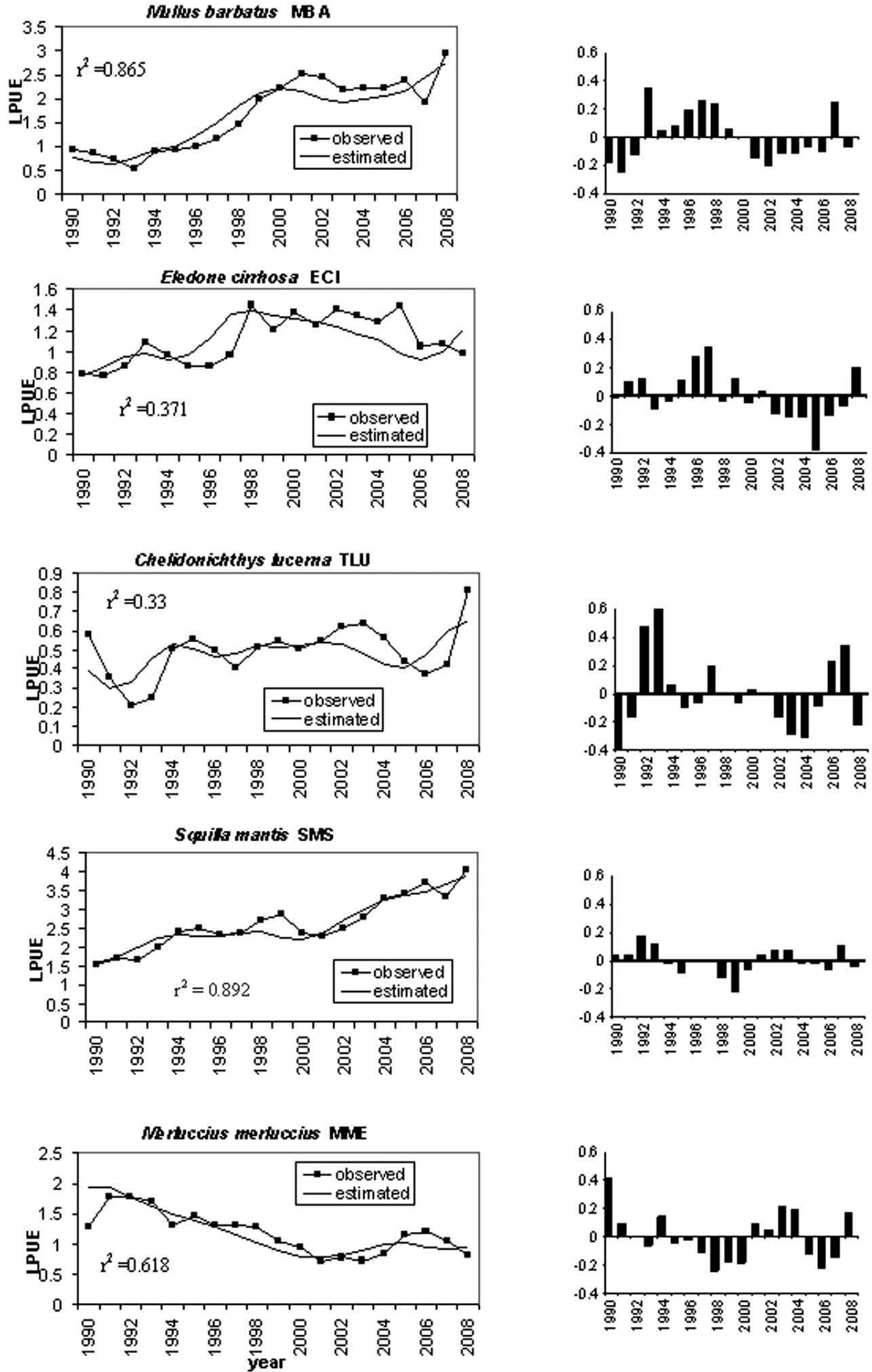

FIG. 3. - Observed and estimated LPUEs (kg/hour) by year for each species individually and for the whole assemblage.Log residuals between the observed and estimated values are shown on the right. 

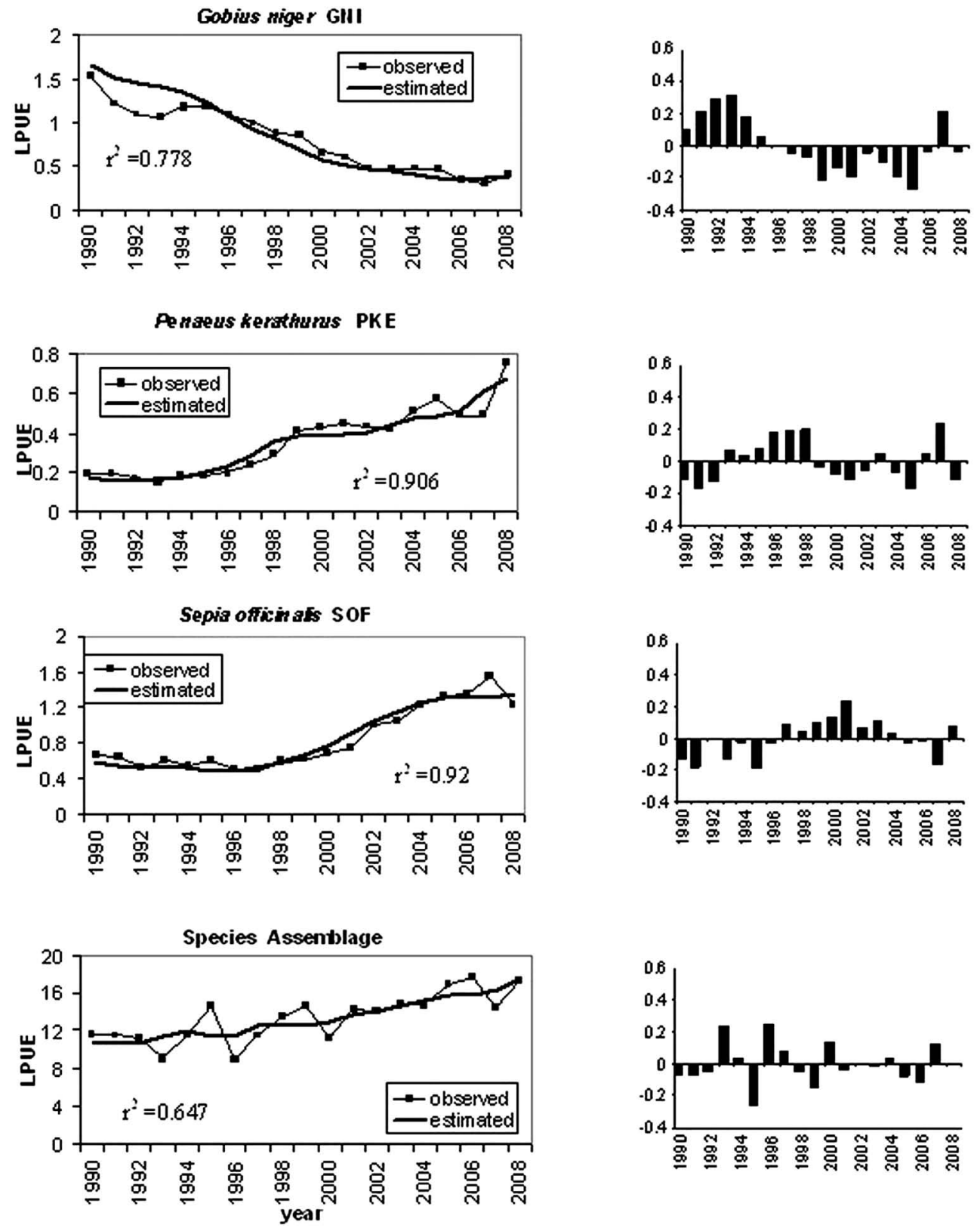

FIG. 3 (cont.). - Observed and estimated LPUEs (kg/hour) by year for each species individually and for the whole assemblage.Log residuals between the observed and estimated values are shown on the right.
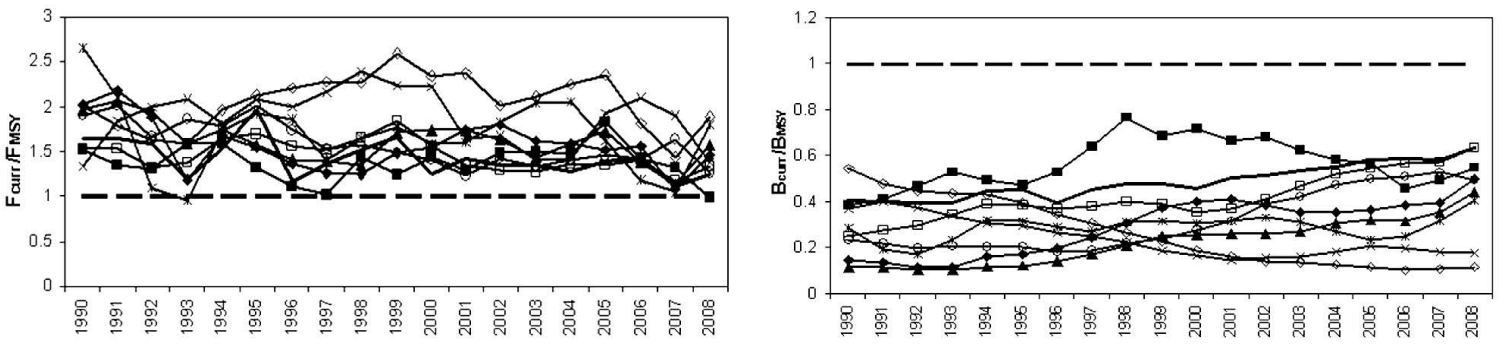

\begin{tabular}{|c|c|c|}
\hline -assemblage & $\approx \mathrm{TLU}$ & $\multimap \mathrm{SOF}$ \\
\hline —SMS & 士PKE & \#-MME \\
\hline${ }_{-M B A}$ & $\rightarrow$ GHII & $\rightarrow-E C l$ \\
\hline
\end{tabular}

FIG. 4. - Trends of $F_{c u r r} / F_{M S Y}$ (up) and $B_{c u r r} / B_{M S Y}$ (down) rates for each selected species and for the assemblage. See Table 1 for species codes. 


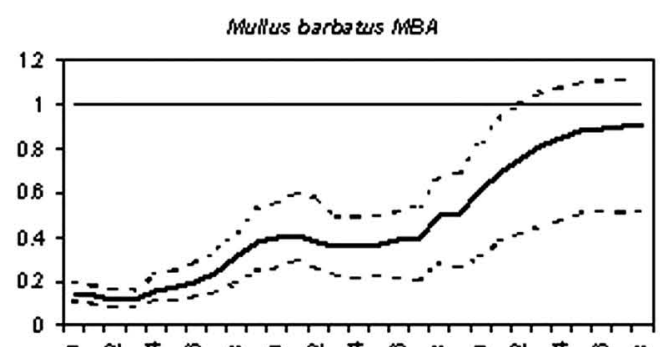

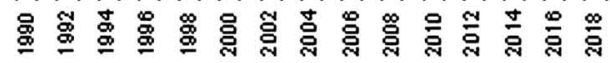
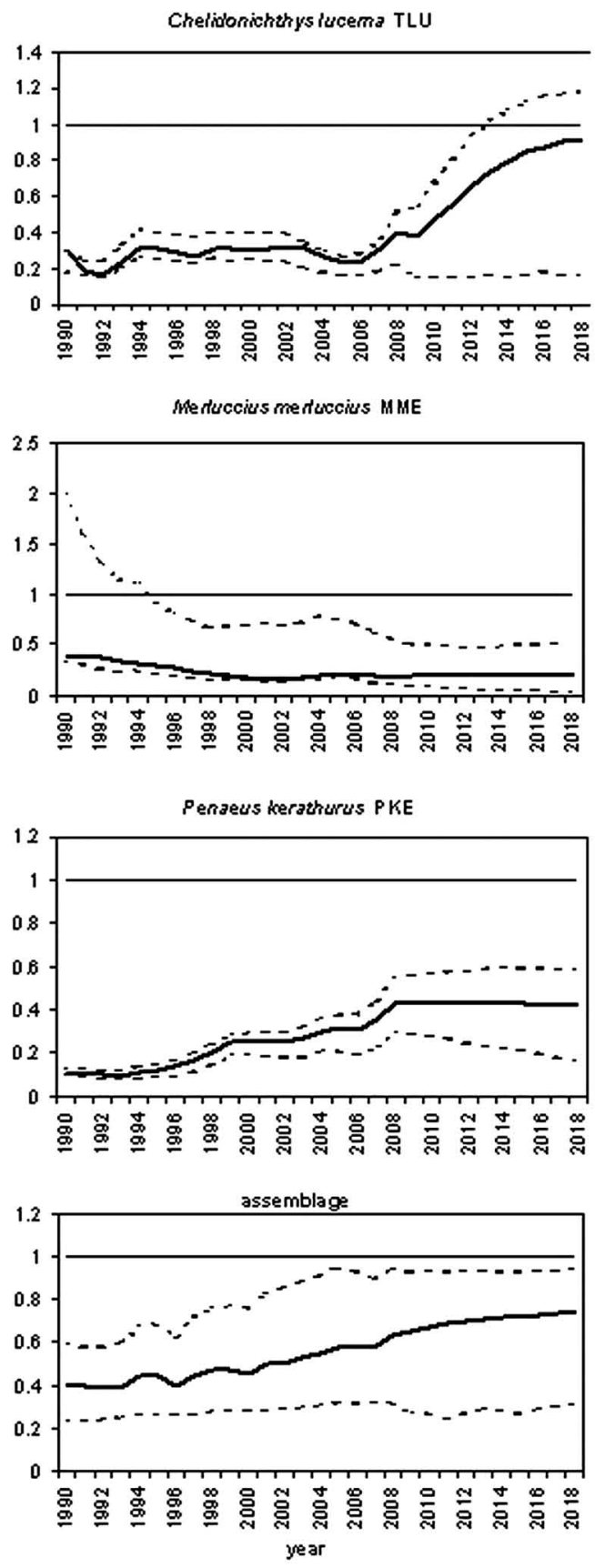
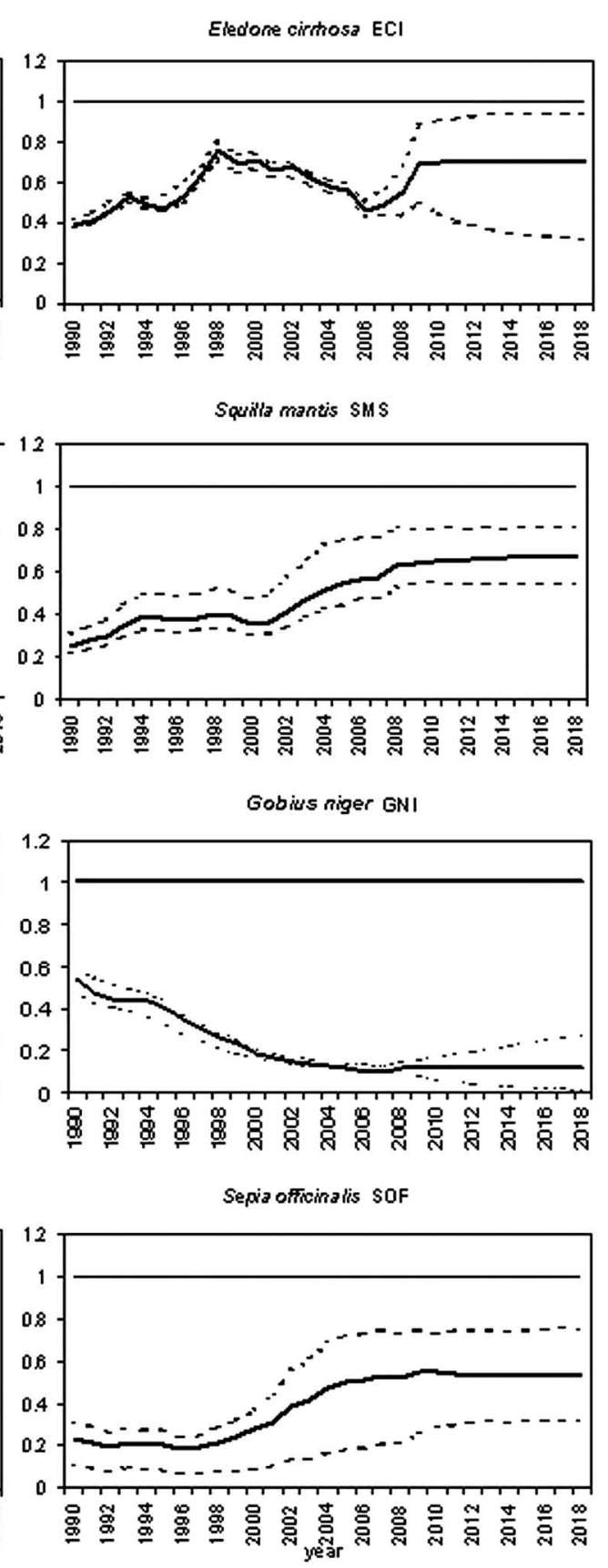

FIG. 5. - Forecasting for the next 10 years (2009-2018) of the $B_{c u} / B_{M S Y}$ rate for each species individually and for the whole assemblage, setting $F$ at a level corresponding to the value of the last year. The dotted lines represent the upper and lower $80 \%$ confidence bounds. The points of years 1990 to 2008 represent the past trajectory. 
TABLE 3. - Approximate time (years) needed for reaching the $B_{M S Y}$ at different levels of reduction of $F$ for each single species and for the assemblage. The cells marked with X represent levels of reduction of $F$ at which the biomass of the species in the analysed time period of 10 years will never reach $B_{M S Y}$. The maximum fraction of $B_{M S Y}$ attainable is also reported in the same cells. See Table 1 for species codes.

\begin{tabular}{|c|c|c|c|c|c|c|}
\hline & $100 \%$ & $80 \%$ & $60 \%$ & $40 \%$ & $20 \%$ & $0 \%$ \\
\hline MBA & 2 & 3 & 3 & 4 & 5 & $\stackrel{x}{x}$ \\
\hline ECI & 2 & 2 & 3 & 3 & $\begin{array}{c}\mathrm{x} \\
0.96\end{array}$ & $\begin{array}{c}\mathrm{X} \\
0.71\end{array}$ \\
\hline TLU & 3 & 3 & 4 & 5 & 6 & $\begin{array}{c}\mathrm{x} \\
0.91\end{array}$ \\
\hline SMS & 2 & 3 & 4 & 5 & $\begin{array}{c}\mathrm{x} \\
0.81\end{array}$ & $\begin{array}{c}\mathrm{x} \\
0.67\end{array}$ \\
\hline MME & 5 & 7 & 10 & $\begin{array}{c}\mathrm{x} \\
0.67\end{array}$ & $\begin{array}{c}\mathrm{x} \\
0.35\end{array}$ & $\begin{array}{c}\mathrm{X} \\
0.2\end{array}$ \\
\hline GNI & 7 & 9 & $\begin{array}{c}\mathrm{X} \\
0.9\end{array}$ & $\begin{array}{c}\mathrm{x} \\
0.52\end{array}$ & $\begin{array}{c}\mathrm{x} \\
0.26\end{array}$ & $\begin{array}{c}\mathrm{x} \\
0.12\end{array}$ \\
\hline PKE & 2 & 3 & 4 & 7 & $\begin{array}{c}\mathrm{x} \\
0.72\end{array}$ & $\begin{array}{c}\mathrm{x} \\
0.43\end{array}$ \\
\hline SOF & 3 & 3 & 3 & 5 & $\begin{array}{c}\mathrm{x} \\
0.81\end{array}$ & $\begin{array}{c}\mathrm{x} \\
0.53\end{array}$ \\
\hline Assemblage & 2 & 3 & 3 & 5 & $\begin{array}{c}\mathrm{x} \\
0.98\end{array}$ & $\begin{array}{c}\mathrm{X} \\
0.74\end{array}$ \\
\hline
\end{tabular}

the single species and for the species mix were much higher than their corresponding $f_{M S Y}$ and $F_{M S Y}$. The demersal assemblage appears severely depleted and even though fishing effort has decreased, the current harvest levels are too high for the stocks to rebuild to $B_{M S Y}$.

Figure 4 shows the relative values of the current fishing mortality rate $F$ and of biomass in relation to the values of $F$ and $B$ at the level of the Maximum Sustainable Yield $\left(F_{\text {cur }} / F_{M S Y}\right.$ and $\left.B_{\text {curr }} / B_{M S Y}\right)$. Values of 1 occur when $F$ or $B$ equal the estimated values of their respective reference points $F_{M S Y}$ and $B_{M S Y}$. As can be seen in the figure, the value of $F$ along the whole analysed period is markedly higher than the $F_{M S Y}$ (on average over 1.5 times). The current biomasses are much lower than $B_{M S Y}$ (on average they are about $20-30 \%$ of $B_{M S Y}$ ) for all the species, which means that the current biomasses are on average about $10-15 \%$ of their pristine levels.

Abundance enhancements were predicted with the forecasting routine for almost all the species with the scenario that effort is kept at the level of the last year. Figure 5 shows the the $B_{\text {cur }}, B_{M S Y}$ rates predicted for 2009 to 2018 for each single species and for the whole assemblage with $F$ at the 2008 level. At this mortality rate, the figure shows that the biomass will not reach the $B_{M S Y}$ level for any of the species.

Projections for some of the species suggest a relatively fast population recovery in the case that effort is reduced. Table 3 shows the estimated time needed to reach $B_{M S Y}$ for each species at different levels of reduced fishing mortality.

In the complete absence of harvest, the approach predicts the rebuilding time to $B_{M S Y}$ to vary from 2 to 7 years, depending on species. Simulations suggest that a $40 \%$ reduction of fishing effort for almost all the species would be needed for the biomass to reach the MSY levels (Fig. 6). For M. merluccius and G. niger, however, at this level of effort reduction, the population biomass would still be very low, and

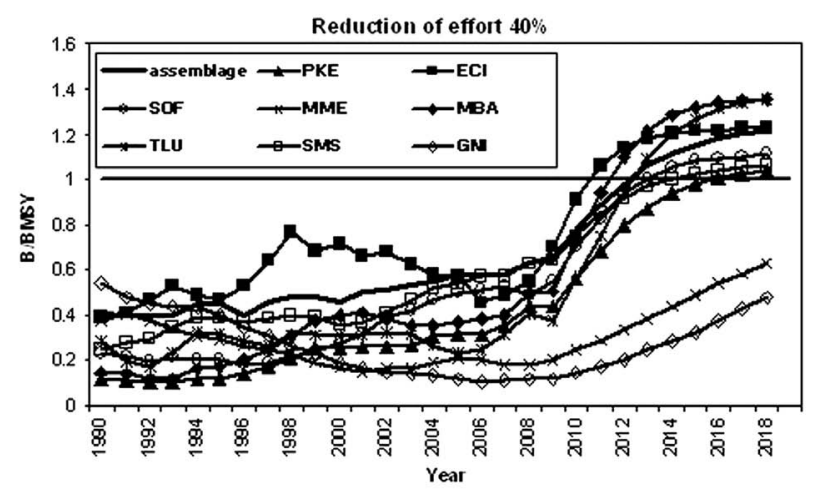

FIG. 6. - Medium-long term changes in relative Biomass $\left(B / B_{M S Y}\right)$ derived from reducing fishing effort by $40 \%$. The vertical line indicates the time horizon set in the World Summit on Sustainable Development for stock rebuilding at MSY level (EC, 2006).

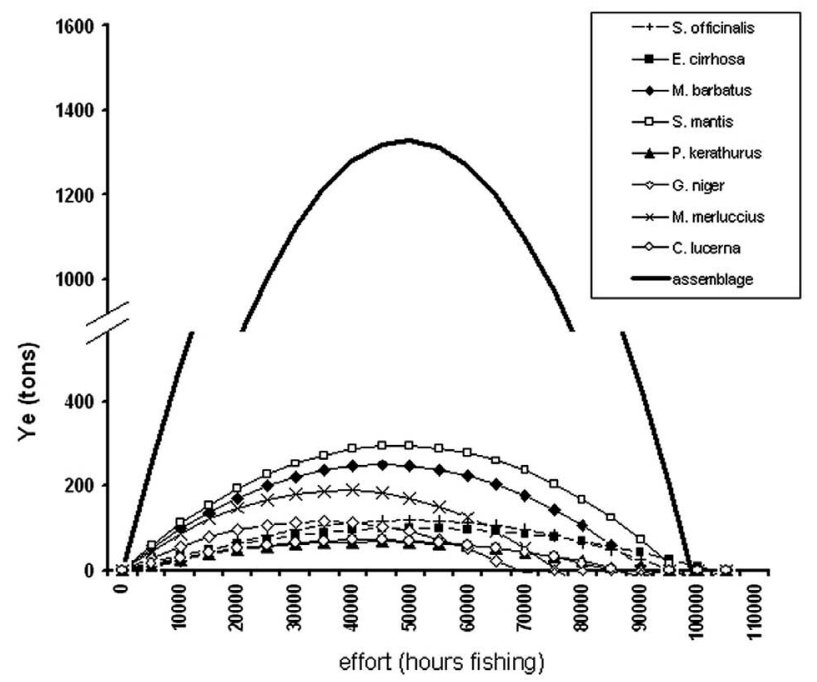

FIG. 7. - Equilibrium yield curves for the 8 species and for the species assemblage assuming a Schaefer model. The vertical line indicates the current level of fishing effort in effective hours fishing. 
hence it is expected that rebuilding to $B_{M S Y}$ will take more than 10 years for the first species while it is unlikely to occur in the case of G. niger. In any case, the biomass levels of these two species are expected to reach $67 \%$ and $52 \%$ of the respective $B_{M S Y}$ values after ten years with a further (albeit modest) increase in the successive years.

Figure 7 shows the equilibrium yield curves for each of the 8 selected species and for the entire assemblage with the different the effort levels. The current level of annual effort estimated as 61726 fishing hours is excessive for all the species because it is well beyond their $f_{M S Y}$ levels. The situation of G. niger is particularly critical. A reduction in the effort level of about $35-40 \%$ should allow all the species to reach a safer and more productive status.

\section{DISCUSSION}

Most of the European Union fish stocks are managed by setting annual total allowable catches (TACs); however, this strategy is difficult to apply, especially in multispecies fisheries, as is the case of most Mediterranean fisheries. According to Rijnsdorp et al. (2006) it is almost impossible to synchronically deplete TACs defined for the different species, and therefore fishing activity continues in practice even when the TAC for some species has already been reached. The individuals belonging to the over-quotas are discarded or illegally landed. In these cases fishing mortality is not constrained by the TAC. Moreover, unreliable catch statistics produce inaccurate assessments and uncertainty in the advice.

Management of Mediterranean fisheries is not based on defining TACs but rather on controlling capacity and fishing effort. However, assessments of fishing effort are based on national statistical data that often do not provide precise or accurate information on the current level of fishing pressure, exploitation patterns, or how effort is divided by fishing strategy and area. Important variables such as the fluctuations in fish stock, the uncertainty related to population size and dynamics, as well as the inherent spatial components of commercial catch data and their variability in the area have seldom been taken into consideration for stock assessment purposes.

In multispecies multigear fisheries, depending on the structural characteristics of vessels, gears in use, operational aspects, fishing traditions, market or other economical constraints, different proportions of a fleet target different species or species mixes. The use of a gear depends on abundance or availability of the species or on market or industry demand, and hence the distribution of effort in time and space is conditioned by the target species. The fishers' choice of fishing gear, depth range, bottom characteristics and season define the species assemblages that will be caughtIn order to assess the real impact of the different fisheries on the exploited assemblages and on each species individually, the total catch and effort have to be partitioned among the various techniques used by the fleet.

Assessments and management advice has to be based on groups of vessels which have the same target species, use the same port and gear type, fish in the same fishing grounds, have the same fishing time, and follow similar landing and commercialisation procedures.

Catch assessment surveys constitute the traditional data source for stock assessment; however, collecting good quality commercial catch and effort data is not easy and requires a lot of work. In the Mediterranean, researchers have generally used single species based stock assessment approaches with data from trawl surveys (analysis of time series of abundance or mortality rates, yield-per-recruit, etc.). While trend analyses allow evident changes in population size to be identified, they do not provide estimates of stock status as relative biomass $\left(B_{\text {cur }} / B_{M S Y}\right)$ and relative fishing mortality $\left(F_{\text {curr }} / F_{M S Y}\right)$ can do (Caddy, 1998).

The enhancement of the quantity and quality of information on commercial fleet activity in the Mediterranean has made it possible over the last years to use age-based methods as well as production models. An example is the catch assessment survey that began in 1990 in the Viareggio port that has allowed the biomass dynamic approach discussed here to be used.

The model using the parameters estimated with the ASPIC fits the data of all the species and of the species complex well. Even though it is quite difficult to evaluate the reliability of the estimated parameters, the results appear consistent with what we know of the fishery: the total catches, the relative abundance of the species, the evolution of the fishery in the analysed period, and the results of previous assessments carried out with alternative approaches.

Some rough indication of expected values of $K$ or $M S Y$ can be derived from a preliminary analysis of the information from commercial catches or from direct biomass estimates from trawl surveys.

As also occur for other biomass dynamic models, the estimates of $K$ in ASPIC are less precise than those of other output parameters. Moreover, the time series does not include the years before the development of the fishery. These years are very informative and including them often increases precision. Considering that there is strong covariance between some estimates, as in the case of $r$ and $K$, as well as the imprecision of the measure of some parameters, Punt and Hilborn, (1996) and Prager, (2005) state that some relative levels of stock biomass, such as $B_{\text {curr }} / B_{M S Y}$ or the exploitation rate $F_{\text {curr }} / F_{M S Y}$, should be used instead of the absolute values because they can be estimated more precisely, and hence using them would supply a more precise picture of the condition of the stock. For instance, absolute levels of stock biomass include uncertainty in the estimate of $q$ that normalisation cancels out.

For the parameter $r$, which is very difficult to measure in wild populations, there are few estimates 
that could be used for comparisons in literature. Some general indications on the common range of $r$ values are available in the literature, often linked with natural history features. Punt and Hilborn (1996) suggest reasonable values for $r$ based on natural mortality rates. They suggest that $r$ values can range from about 0.2 for stocks with low $M$ to more than 1 for very short-lived species. Blueweiss et al. (1978) defined an empirical relationship between body weight and $r$ for several organisms, including fish. Pauly (1984) updated the set of $r$ values and derived new parameters for the Blueweiss equation. The values obtained with ASPIC for the different species are similar, or in some cases lower, than those that can be obtained with the above mentioned equation. Cortes (2000) also related $r$ to natural history features, such as longevity, age at maturity $t_{m}$ and generation length $G L$, of some Chrondrichtyan species. For Prionace glauca, assuming that longevity is equal to13 years, $t_{m}=4.5$ and $G L=6.89$, this author estimated a value of 0.328 . For Dipturus laevis, using life tables, Gedamke et al. (2007) estimated an $r$ value of 0.45 . Bousquet et al., (2008) estimated a value of $r=0.4$ for Georges bank haddock and 0.33 for albacore. Cadrin, (1999) estimated an $r$ value of 0.6 for Georges Bank yellowtail flounder, while for hake species, values between 0.3 and 0.4 were found for Merluccius capensis in Namibia (Polachek et al., 1993), 0.722 for Merluccius productus in the Gulf of Maine, (Caddy and Defeo,1996) and 0.79 for Merluccius merluccius in Greek waters (Tserpes et al., 2007). For species with a lower lifespan, relatively high $r$ values have been reported. Eggert and Martinsson (2003) estimated $r=0.658$ for anchovy and Ye and Rosenberg (1991) determined an $r$ value of 2.5 for the short-lived sable fish Trichiurus haumela in the China Sea.

Most of the species analysed here are relatively short-lived species with a fast turnover. For the European hake, frequently considered a long-lived species, recent findings derived from mark-recapture experiments, suggest a faster growth rate for the species. This finding modifies the perception of the species population dynamics and suggests that it has an early age of maturity and high natural mortality rate. Assuming for the species a mean natural mortality rate of about 0.4 0.5 , which is also consistent with $\mathrm{M}$ vectors declining with age derived from multispecies VPA for gadoids, the value of 0.57 estimated with the ASPIC does not appear to be far from the guess value that is obtained according to the rules of thumb proposed by Punt and Hilborn (1996). Values of $r$ around 1.0 seem reasonable for the cephalopods and crustaceans included in the analysis and also for Mullus barbatus and Chelidonichthys lucerna, which are considered relatively fast growing short-lived species.

The relatively high values of $r$ for the species involved in the fishery are likely to constitute an important factor that contributes to the sustainability of this fishing activity, which is exerted by a large number of vessels on a small fishing area.
The results of the assessments presented here are consistent with the available previous assessments for the same area and resources (Abella and Serena, 1998; Abella et al., 2005 a, b). Despite the generalised high overexploitation status, the observed positive trend of the abundance index LPUE for almost all the species and for the whole assemblage is consistent with the abundance indices derived from trawl surveys in the area and with what can be expected considering the reduction in the number of vessels observed over the studied period, shown in Figure 3.

M. merluccius, for example, shows a wide spatial and bathymetric distribution that extends further than the boundaries of the fishing grounds of the coastal demersal fishery and is exploited by other fractions of the fleet. Therefore, the results for this species might be biased and less reliable. Although using a surplus model for this species may not be completely appropriate, this species was included in the analyses due to its great importance in the overall landings of the coastal trawlers. A decreasing trend in LPUE was observed up to the year 2000, followed by an almost steady state situation. This change in the general trend, although with large confidence intervals, could be interpreted as a delayed response of this species to a reduction in the overall effort targeting the species that started in the late $90 \mathrm{~s}$.

In the case of black goby $G$. niger, the approach used is probably not sufficient for modelling certain key issues of the species population dynamics. There is an objective difficulty for linking the negative evolution of the species biomass with the reduction in fishing pressure. Some hypotheses can be formulated to explain the observed trend. For instance, it may be related to the relatively low fecundity of the species, an increase in biomass of some competitors of Gobius. niger that compete for food or space, and/or the negative impact of the continuous destruction of nests and benthic eggs as a result of the mechanic action of trawl nets on the grounds.

The results obtained with the forecasting routine of ASPIC, assuming the level of effort is fixed to the value of the last year, suggest an increase in abundance for almost all the species of the coastal groundfish assemblage (Fig. 5). The expected levels of biomass obtained by not changing the mortality rates are insufficient to maximise yields (by approaching $B_{M S Y}$ ) and guarantee sustainability.

Recently, a panel of experts (NEFSC, 2008) revised the assessments of the North American stocks managed under the Northeast Multispecies Fishery Management Plan considering the overall production potential of the fishery based on food chain processes. They compared advice derived from aggregate single stock yield projections with that derived from overall ecosystem production, and identified potential inconsistencies. The results from single species and aggregated species surplus production suggest that "the expected aggregate yield is lower, the $B_{M S Y}$ is lower and the overall 
fishing mortality rate should be lower for the stocks as a whole than those suggested from the single species results". The aggregate scenarios produce more conservative results, which implies that there may be some systemic or model structural limitations in the aggregate scenario that are more fully captured than when a more species-specific approach is employed. They concluded that it is still unclear if $B_{M S Y}$ for all species will be energy limited from a systemic perspective.

As regards the possibility of all species reaching their $B_{M S Y}$ levels in the context of a multispecies fishery, it is suggested that the ecosystem is unlikely to be able to sustain all stocks at their single-species $B_{M S Y}$ levels simultaneously. The analyses have shown that the production model for the sum of species provides an aggregate $B_{M S Y}$ estimate that is lower than the value obtained by summing the single estimates from species-specific production models. The aggregated MSY is also lower than the value obtained by summing the estimates from each single species production model. The panel of experts also noted that the aggregated $F_{M S Y}$ estimate was lower than most estimates from single-species models. This characteristic was also observed in the present analysis.

Considering the sum of the estimated values of $B_{M S Y}$ for the 8 species considered in this analysis, this value represents over $70 \%$ of the $B_{M S Y}$ estimated for the whole assemblage (which contains more than 40 species) while the sum of the single $M S Y$ of these 8 species represents over $90 \%$ of the estimated value for the assemblage. In addition, the $F_{M S Y}$ estimated for the assemblage is generally lower than those defined on a species-specific basis.

The results of this study, considering the current catch and effort levels related to $M S Y$ and the need for some sort of compromise based on a precautionary approach, suggest that a reduction in fishing effort of about $40 \%$ of the current level of $f$ is advisable. With this reduction, the biomasses are expected to approach $B_{M S Y}$ for almost all the species and produce a relatively high long-term increase in overall yields. It is likely that biomass at this effort level will reach $0.67 B_{M S Y}$ for M. merluccius and about $0.5 B_{M S Y}$ for $G$. niger at the medium-term.

The progressive although modest reduction in fishing effort that occurred over the analysed period is considered to have led to the observed enhancements in the catch rates. Reductions from $20 \%$ to $40 \%$ of the current $F$ and 5 years on average are needed for all the species to reach $B_{M S Y}$, except for M. merluccius and G. niger. It is important to note that the biomass levels expected from a $40 \%$ reduction in fishing effort are in line with the time horizon set in the Johannesburg Word Sustainable Development Summit and with the EU policy of 2015 (EC, 2006).

In the case of G. niger, which is the species considered to be in the worst condition, a more drastic reduction (about 75\%) and more time (about 8-10 years) would be needed to reach the $B_{M S Y}$ reference level.
For G. niger and for the European hake, the expected results of any management action are more uncertain considering that, due to the above mentioned special features, the usefulness of the approach for these species is questionable.

The analysis demonstrated that the available time series of catch and specific effort data was useful for defining a reference value of fishing effort for a species assemblage exploited by a trawler fleet operating near the coast. The approach allowed a reference point in terms of fishing effort to be defined. This is extremely useful in the case of most of the Mediterranean fisheries, which are managed based on fleet capacity and activity. It is worth noting that it was possible to use this approach because a quantification and partitioning in time and space of fishing effort by fishing strategy was available. This is a critical issue in the case of most of the Mediterranean multispecies-multigear fisheries.

In analyses conducted on the Italian coasts, and in particular in the southern Ligurian-northern Tyrrhenian Seas, large regional differences in coastal species abundance trends have been observed. While the species inhabiting the Viareggio grounds have undergone a general increase in recent years, other neighbouring populations have remained stable or decreased. It is likely that these contrasting trends are mainly linked to the evolution of the fishing pressure in the different areas. Future production models applied to these other areas will hopefully clarify these trends and allow managers to determine regional harvest regulations. By identifying appropriate management measures for each region, we can improve our ability to rebuild the coastal demersal populations and provide sustainable resources for the different fisheries.

\section{REFERENCES}

Abella, A. and F. Serena. - 1998. Stato di sfruttamento del nasello nei compartimenti di pesca di Livorno e Viareggio. Biol. Mar. Medit., 5(2): 136-150.

Abella, A., F. Serena, L. Fortunati, U. Mammini, D. Lari and R. Ciardelli. - 2001. Use of GIS for the analysis of spatial data on fishing effort and seasonal changes in fishing strategies for Tyrrhenian Sea bottom trawl fisheries. In: T. Nishida, C.E. Hollingworth, and P. Kailola (eds.), Proceedings of the First International Symposium on GIS in Fishery Science, pp. 119-129. Seattle, WA, 2-4 March 1999. Fishery GIS Research Group, Kawagoe, Saitama, Japan.

Abella, A., P. Carpentieri, A. Mannini, M. Ria, P. Sartor, C. Viva and A. Voliani. - 2005a. Use of fisheries independent data for the definition of the stock status of Mullus barbatus utilizing mortality rates based reference points. 7th Meeting of the SubCommittee on Stock Assessment (SCSA) FAO, Rome, 26-30 September, 2005.

Abella, A., M. Ria and F. Serena. - 2005b. Usefulness of legal size for the recovery of a European hake stock in a North-western Mediterranean bottom trawl fishery. ICES CM 2005/W: 19.

Booth, A.J. and A.E. Punt. - 1998. Evidence for rebuilding in the panga stock on the Agulhas Bank, South Africa. Fish. Res., 34: 103-121.

Bousquet, N., T. Duchesne and L. Rivest. - 2008. Redefining the maximum sustainable yield for the Schaefer population model including multiplicative environmental noise. J. Theor. Biol, 254: 1-26.

Blueweiss, L., M. Fox, V. Kudzma, D. Nakashima, R. Peters and S. Sams. - 1978. Relationship between body size and some life- 
history parameters. Oecologia, 37: 257-272.

Caddy, J. - 1998. A short review of precautionary reference points and some proposals for their use in data-poor situations. FAO Fish. Tech. Pap., 379, Rome. 29 pp.

Caddy, J. F. and O. Defeo. - 1996. Fitting the exponential and logistic surplus yield models with mortality data: some explorations and new perspectives. Fish. Res., 25: 39-62.

Cadrin, S. - 1999. A Precautionary Approach to Fishery Control Rules Based on Surplus Production Modeling. Proceedings, 5th NMFS NSAW. 1999. NOAA Tech. Memo. NMFS-F/SPO-40.

Cadrin, S.X. and. E.M.C Hatfield. - 2002. Relative biomass and production of long fin inshore squid, Loligo pealeii. Bull. Mar. Sci., 71: 1115-1116.

Carbonell, A. and M. Azevedo. - 2003. Application of non-equilibrium production models to the red shrimp (Aristaeus antennatus, Risso, 1816) fishery in the northwestern Mediterraenan. Fish. Res., 65: 323-334

Cortes, E. - 2000. Potential rates of increase and rates of increase for generation for three species of pelagic sharks from the Atlantic Ocean. Coll. Vol. Sci. ICCAT, 51(6): 1822-1828.

EC. - 2006. Commission of the European Communities. Communication from the Commission to the Council and the European Parliament. Implementing sustainability in EU fisheries through maximum sustainable yield. $\operatorname{COM}(2006) / 360$. http://europa. eu/legislation_summaries/maritime_affairs_and_fisheries/ fisheries_resources_and_environment/166037_en.htm

Efron, B.E. and G. Gong. - 1983. A leisurely look at the bootstrap, the jackknife, and cross validation. Am. Stat., 47: 36-48.

Eggert, H. and P. Martinsson. - 2003. Commercial fishers and expected utility. XV EAFE Conference, IFREMER, Session 12 Fisheries Dynamics.

Gedamke, T., J.M. Hoenig, J.A. Musick, W. DuPaul and S.H. Gruber. - 2007. Using demographic models to determine intrinsic rate of increase and sustainable fishing for elasmobranches: Pitfalls, Advances and Applications. N. Am. J. Fish. Manag., 27: 605-618

Hilborn, R. and C.J. Walters. - 1992. Quantitative Fisheries Stock Assessment. Choice, Dynamics and Uncertainty. Chapman and Hall.

Ludwig, D. and C.J. Walters. - 1989. A robust method for parameter estimation from actch and effort data. Can. J. Fish. Aquat. Sci., 46: 137-144

NEFSC. - 2008. Panel Summary Report of the Groundfish Assessment Review Meeting (GARM III) Part 3. Biological Reference Points. 28 April - 2 May 2008 Northeast Fisheries Science Center Reference Document 05-13.

Pauly, D. - 1984. Fish population dynamics in tropical waters. A manual for use with programmable calculations. ICLARM, Stud. Rev., 8: 1-325.

Polachek, T., R. Hilborn and A. Punt. - 1993. Using Surplus Production Models: Comparing Methods and Measuring Uncertainty. Can. J. Fish. Aquat. Sci., 50: 2597-2601

Prager, M. - 1994. A suite of extensions to a non-equilibrium surplus production model. Fish. Bull., 92: 374-389.

Prager, M. - 2005. Users Manual for ASPIC: A Stock-Production Model Incorporating Covariates (ver.5), NMFS, Beaufort Lab. Doc. BL-2004-01.

Prager, M., C.E. Porch, K.W. Shertzer and J.F. Caddy. - 2003. Targets and limits for management of fisheries: a simple probability-based approach. N. Am. J. Fish. Manag., 23: 349-361.

Punt, A.E. and R. Hilborn. - 1996. Biomass dynamic models. User's manual. FAO Computerized Information Series. (Fisheries) No. 10. FAO, $62 \mathrm{pp}$.

Rijnsdorp, A., N. Daan and W. Dekker - 2006. Partial fishing mortality per fishing trip: a useful indicator of effective fishing effort in mixed demersal fisheries. ICES J. Mar. Sci, 63: 556-566.

Schnute, J. - 1977. Improved estimates from the Schaefer production model: theoretical considerations. J. Fish. Res. Bd. Can., 34: 583-603

Tserpes, G., J. Haralabous and D. Maravelias. - 2007 A non-equilibrium surplus production model approach utilizing MEDITS data. FAO-GFCM workshop on trawl survey based monitoring fishery system in the Mediterranean, Rome, 26-28 March 2007.

Prager, M.H. - 2002. Severe decline in abundance of the red porgy, Pagrus pagrus, population of the Atlantic Ocean off the southeastern United States. Fish. Bull., 100: 351-375.

U.S. Department of Commerce. - 1996. Magnuson-Stevens Fishery Conservation and Management Act as amended through October 11, 1996. NOAA Tech. Mem. NMFS-F/SPO-23.

U.S. Department of Commerce. - 1998. Magnuson2Stevens provisions; national standard guidelines. Federal Register 63:84: 24212-24237.

Vaughan, D.S. and M.H. Prager. - 2002. Severe decline in abundance of the red porgy (Pagrus pagrus) population off the southeastern United States. Fish. Bull., 100(2): 351-375.

Ye, Y. and A.A. Rosenberg. - 1991. A study of the dynamics and management of the hairtail fishery, Trichiurus haumela, in the East China Sea. Aquat. Living. Resour., 4(2): 65-75.

Scient. ed.: I. Palomera

Received September 17, 2009. Accepted April 8, 2010.

Published online September 23, 2010. 